\title{
Phenotypic Characterization of Aseel Chicken of Bangladesh
}

\author{
Md. Jonaed Alam Sarker ${ }^{1}$, Mohammad Shamsul Alam Bhuiyan ${ }^{1,+}$, Md. Omar Faruque ${ }^{1}$, Md. Ashraf Ali ${ }^{2}$ and Jun Heon Lee ${ }^{3}$ \\ ${ }^{I}$ Department of Animal Breeding and Genetics, Bangladesh Agricultural University, Mymensingh-2202, Bangladesh \\ ${ }^{2}$ Department of Poultry Science, Bangladesh Agricultural University, Mymensingh-2202, Bangladesh \\ ${ }^{3}$ Department of Animal Science and Biotechnology, Chungnam National University, Daejeon 305-764, Republic of Korea
}

\begin{abstract}
The aim of this study was to investigate phenotypic characteristics, morphometric measurements, reproduction and production performances of Aseel chicken of Bangladesh. The dominant feather color of neck/hackles was red in both males (56.14\%) and females (54.16\%) while the sickle feather color was mostly black in both chickens (71.93\% vs. 54.17\%). The predominant saddle and breast feather colors were red $(40.35 \%)$ and black (64.91\%), respectively, in male whereas most frequent observed color was pale brown in female (58.33 and 50.0\%, respectively). The predominant feather color of wing bow and wing bay was found black (68.42 and $80.70 \%$, respectively) in male but only pale brown color was observed in females (62.5 and $54.17 \%$, respectively) for these two characters. Different phenotypic measurements such as the average shank length and circumference were $12.79 \pm 0.13$ and $7.8 \pm 0.08 \mathrm{~cm}$, respectively, in male and $10.21 \pm 0.25$ and $5.81 \pm 0.21 \mathrm{~cm}$, respectively, in female. Keel length was $14.39 \pm 0.19 \mathrm{~cm}$ in male and $10.79 \pm 0.23 \mathrm{~cm}$ in female. The average adult live weight in male was measured $3749.12 \pm 83.44 \mathrm{~g}$ while in female it was $2062.50 \pm 105.26 \mathrm{~g}$. The age of 1st lay was found to be 28.86 weeks. Total number of eggs laid per year ranged between 24 48, number of clutch/hen/year varied from 2 to 4 and number of eggs/clutch/hen was found to be $10 \sim 12$. The average live weight of Aseel chicken at 1, 2, 3, 4, 6, 8, 10, 12, 16 and 17 weeks of age were recorded as $31.14 \pm 0.55,48.63 \pm 3.99,116.57 \pm 5.72,138.40 \pm 5.91,212.88 \pm 4.82,361.00 \pm 9.72,577.50 \pm 42.86$, $743.75 \pm 24.65,1086.00 \pm 26.02,1402.00 \pm 24.54$ and $1432.00 \pm 27.00 \mathrm{~g}$ respectively. Finally, this phenotypic characterization as well as productive and reproductive performances of Aseel chicken will give the baseline information to researcher for further study and for planning any on-ward conservation and implement strategy.
\end{abstract}

(Key words : phenotype, aseel chicken, production, reproduction performance)

\section{INTRODUCTION}

In Bangladesh, approximately 140 million chickens are scattered throughout 68,000 villages which mostly of indigenous non-descript type (Bhuiyan et al., 2005). About $89 \%$ of the rural households keep chicken with an average of 6.8 birds per holding and are raised under low input system (MOFL, 2004). Indigenous chicken have undergone unknown periods of natural selection and are a reservoir of excellent genetic diversity. They show high level of morphological and phenotypic variability and increased fitness under natural settings (Maeda et al., 1987). Among said indigenous chicken genetic resources, non-descript Deshi, Aseel, Hilly and Naked Neck chickens are noteworthy (Bhuiyan et al., 2005). Aseel chickens are mostly found in Sarail Upazilla under Brahmanbaria district of Bangladesh. This is a game bird, also called fighter bird. It is reported that Aseel had been used to establish modern Cornish breed as one of the male parent lines for development of broilers (Helal, 2002). The origin of the Aseel breed is the landmass known as the Indian subcontinent which includes South Punjab or Sindh areas of India and Pakistan (http:// en.wikipedia.org/wiki/Asil). The Aseel comes from mainly three basic sizes or types; the Reza $(4.5 \sim 7 \mathrm{lbs})$, the Hint (7 $10 \mathrm{lbs})$ and large type $(10 \sim 15.5 \mathrm{lbs})$. Further, within these three basic types there are many sub-varieties, for example, the Kulang (predecessor of the Malay), Madras, Calcutta and Hyderabad (Everett, 2010). The Aseel is a very powerful bird having large bone, with broad shoulders, an upright stance, heavily muscled hips and square shanks, strong and curved neck and short beak (Roberts, 1997). The face is rather predatory looking, pearl-colored eyes, with a small pea comb and ear lobes, and no wattles at all. The tail is carried low and fans horizontally rather than vertically (Holligon, 2001). Eggs are usually tinted and the hens are known for poor laying ability. The breastbone

\footnotetext{
${ }^{\dagger}$ To whom correspondence should be addressed : bhuiyansa@yahoo.com
} 
is left exposed (and often the back of the head and the points of the shoulders). The APA (American Poultry Association) Standard recognizes black breasted red, wheaten, dark, spangled, and white Aseels, but they can also be found in the typical game colors including grey (duckwing), blue breasted red, and black (APA, 1998). Crosses with Aseel make excellent meat birds, even though the pure stock tends to be rather slow maturing (Floyd, 2001; Holligon, 2001).

Aseel chicken is predominantly reared in Sarail upazilla of Brahmanbaria district and is also kept by some of the urban and city dwellers mainly for cock fighting or as hobby. However, this population is in declining trend now as farmers or bird owners are interested to purchase only male birds from India for cock fighting (personal communication). Until to date, much scientific intervention has not yet been given for this valuable genetic resource and very limited information to us about their phenotypes and performances. It is important to characterize Aseel chicken which is available at this moment in Bangladesh, based on their geographical distribution, morphological characteristics and productivity before going to initiate any conservation strategy. So, keeping this in view, the present research work was aimed to study the morphological features of Aseel chicken and to investigate the productive and reproductive performances of Aseel chicken under village and on-station based intensive management conditions.

\section{MATERIALS AND METHODS}

In this study, a total of 20 Aseel bird owners were interviewed randomly from the Sarail upazila of Brahmanbaria district and Joydebpur upazila of Gazipur district which included 81 birds of different ages. Interview was taken respective farmer's residence with a structured questionnaire on the topics such as chicken population and genetic status, phenotypic characteristics, feeding regime, production potential, reproductive performance, disease control and management. Different morphological variants such as plumage colors and patterns, shank color, comb type, skin color, eye color, beak color, ear lobes shape and color were observed only from adult Aseel chicken and recorded accordingly. Morphometric measurements like egg weight, live weight at different ages, shank length, shank cir- cumference, keel length, ulna/radius length were taken by electric weighing balance, measuring tape and slide calipers. When the interview was over, the information was checked carefully before leaving the farmers house and study area, and any confusion was rationalized and corrected by comparing those with local standards to keep consistency of data. In addition, data on growth performance of Aseel chicken up to 17 weeks of age were collected from Bangladesh Agricultural University (BAU) poultry farm. Collected data from the farmer's house and BAU poultry farm were recorded in master table sheets. Descriptive statistics such as mean, range, frequency and percentage were used to analyze the data using Statistical Package for Social Sciences (SPSS, version 11.2).

\section{RESULTS AND DISCUSSION}

The collected information on Aseel chicken was analyzed and is presented in different Tables and Figures accordingly.

\section{Qualitative Traits}

The features of qualitative traits and their distributions are presented in Table 1 and Fig. 1. Yellowish featherless sank was observed in both male and female Aseel birds. Spur was found very prominent. The wattles colors were red and mostly rudimentary $(77.19 \%)$ in male but absent in female. The color of beak was yellow. Ear lobe color was red and mostly smaller in size for both sexes. The pea type comb was found as dominant $(75.95 \%)$, however, strawberry $(24.05 \%)$ type was also observed (Fig. 2). Color of skin was whitish in both males and females but bare skin showed reddish. Eye color was yellowish. Egg shell color was found mostly light brown (77.78\%) but white colored (22.22\%) eggs were also found. All of these observations were in accordance with the American Standard of Perfection (APA, 1998) and British Poultry Standard (Roberts, 1997) except for wattles, comb type and egg shell color. They reported no wattle, only pea type comb and brownshelled eggs in Aseel chicken. These deviations might be due to admixture of this breed with other game birds. In another study, Everett (2010) reported that Aseel bird typically possessed a pea comb though the cushion comb is not uncommon which supports the present findings. 
Table 1. Qualitative traits and its frequency in Aseel chicken of Bangladesh

\begin{tabular}{|c|c|c|c|c|}
\hline Traits & $\operatorname{Sex}^{*}$ & $\mathrm{n}^{*}$ & Characteristic features & Frequency $(\%)$ \\
\hline Shank color & $\mathrm{M} / \mathrm{F}$ & 81 & Yellowish & 100 \\
\hline Shank feathering & $\mathrm{M} / \mathrm{F}$ & 81 & No feathering & 100 \\
\hline Spur & M & 81 & Large spurs & 100 \\
\hline Number of toes & $\mathrm{M} / \mathrm{F}$ & 81 & Four toes & 100 \\
\hline \multirow{3}{*}{ Wattles } & \multirow{2}{*}{ M } & \multirow{2}{*}{57} & Medium size & 22.81 \\
\hline & & & Rudimentary & 77.19 \\
\hline & $\mathrm{F}$ & 24 & Absent & 100 \\
\hline Beak color & $\mathrm{M} / \mathrm{F}$ & 81 & Yellow & 100 \\
\hline \multirow{3}{*}{ Ear lobe shape } & \multirow{2}{*}{ M } & \multirow{2}{*}{57} & Small & 75.40 \\
\hline & & & Medium & 24.60 \\
\hline & $\mathrm{F}$ & 24 & Small & 100 \\
\hline Ear lobe color & $\mathrm{M} / \mathrm{F}$ & 81 & Red & 100 \\
\hline \multirow{2}{*}{ Comb type } & \multirow{2}{*}{$\mathrm{M} / \mathrm{F}$} & \multirow{2}{*}{79} & Pea comb & 75.95 \\
\hline & & & Strawberry comb & 24.05 \\
\hline Skin color & $\mathrm{M} / \mathrm{F}$ & 81 & $\begin{array}{l}\text { Whitish (except bare skin of breast and wing } \\
\text { joints and thighs, which showed red ) }\end{array}$ & 100 \\
\hline Eye color & $\mathrm{M} / \mathrm{F}$ & 81 & Yellowish & 100 \\
\hline \multirow{2}{*}{ Egg color } & \multirow{2}{*}{$\mathrm{F}$} & 14 & Light brown & 77.78 \\
\hline & & 4 & White & 22.22 \\
\hline
\end{tabular}

${ }^{*} \mathrm{n}=$ number of observation, $\mathrm{M}=$ male and $\mathrm{F}=$ female.
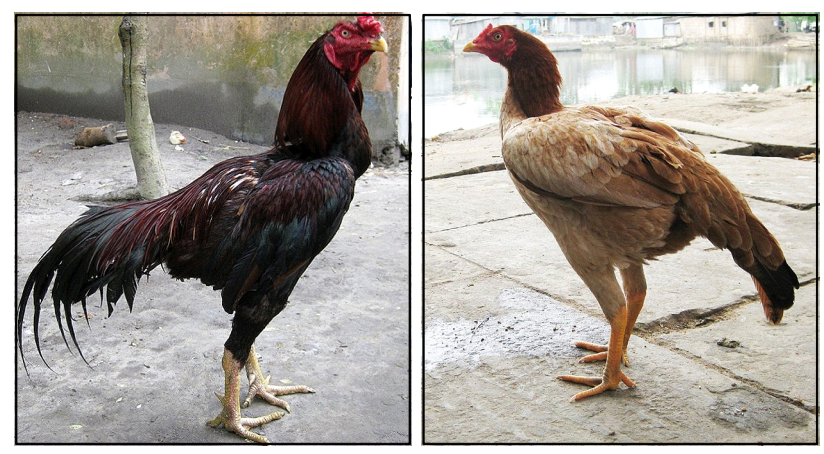

Fig. 1. The images represent mature Aseel male and female.

\section{Feather Color Distribution}

Feather color distribution and its frequency in Aseel male and female are presented in Table 2 . The results indicate that the dominant feather color of neck/hackles was observed red in both males (56.14\%) and females (54.16\%). Sickle feather

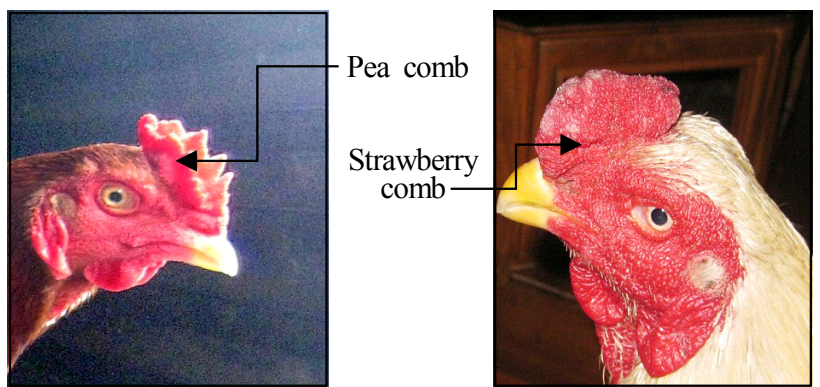

Fig. 2. The images represent comb types in Aseel chicken.

color was mostly black in both males (71.93\%) and females (54.17\%). The predominant saddle feather color was red (40.35\%) in male but pale brown (58.33\%) in female. Breast feather color was mostly black (64.91\%) in male and pale brown $(50 \%)$ in female. The predominant color of wing bow and wing bay was found black (68.42 and $80.70 \%$, respectively) in 
Table 2. Distribution and frequency of feather color in Aseel chicken

\begin{tabular}{|c|c|c|c|c|c|c|c|c|c|c|c|}
\hline \multirow{3}{*}{ Name of feather } & \multicolumn{11}{|c|}{ Feather color frequency $(\%)$} \\
\hline & \multicolumn{5}{|c|}{ Male } & \multicolumn{6}{|c|}{ Female } \\
\hline & Black & White & Red & $\begin{array}{c}\text { Black } \\
\text { and } \\
\text { White }\end{array}$ & $\begin{array}{c}\text { Black } \\
\text { and } \\
\text { Red }\end{array}$ & Black & White & Red & $\begin{array}{l}\text { Pale } \\
\text { Brown }\end{array}$ & $\begin{array}{c}\text { Black } \\
\text { and } \\
\text { White }\end{array}$ & $\begin{array}{c}\text { Black } \\
\text { and } \\
\text { Red }\end{array}$ \\
\hline $\begin{array}{l}\text { Neck/Hackles feather } \\
\text { color }\end{array}$ & $\begin{array}{l}7.01 \\
(4)\end{array}$ & $\begin{array}{c}14.03 \\
(8)\end{array}$ & $\begin{array}{c}56.14 \\
(32)\end{array}$ & $\begin{array}{c}10.52 \\
(6)\end{array}$ & $\begin{array}{c}12.28 \\
(7)\end{array}$ & $\begin{array}{c}4.17 \\
(1)\end{array}$ & $\begin{array}{c}4.17 \\
(1)\end{array}$ & $\begin{array}{c}54.16 \\
(13)\end{array}$ & - & $\begin{array}{c}16.67 \\
(4)\end{array}$ & $\begin{array}{c}20.83 \\
(5)\end{array}$ \\
\hline Sickle feather color & $\begin{array}{c}71.93 \\
(45)\end{array}$ & $\begin{array}{l}3.50 \\
(2)\end{array}$ & $\begin{array}{l}8.77 \\
(5)\end{array}$ & $\begin{array}{c}17.54 \\
(10)\end{array}$ & - & $\begin{array}{l}54.17 \\
(13)\end{array}$ & $\begin{array}{c}4.17 \\
(1)\end{array}$ & $\begin{array}{c}20.83 \\
(5)\end{array}$ & - & - & $\begin{array}{c}20.83 \\
(5)\end{array}$ \\
\hline Saddle feather color & $\begin{array}{c}17.54 \\
(10)\end{array}$ & $\begin{array}{c}10.52 \\
(6)\end{array}$ & $\begin{array}{l}40.35 \\
(28)\end{array}$ & $\begin{array}{c}10.52 \\
(6)\end{array}$ & $\begin{array}{l}12.28 \\
(7)\end{array}$ & $\begin{array}{c}20.83 \\
(5)\end{array}$ & $\begin{array}{l}4.17 \\
(1)\end{array}$ & - & $\begin{array}{c}58.33 \\
(14)\end{array}$ & $\begin{array}{l}12.5 \\
(3)\end{array}$ & $\begin{array}{c}4.17 \\
(1)\end{array}$ \\
\hline Breast feather color & $\begin{array}{c}64.91 \\
(37)\end{array}$ & $\begin{array}{l}3.51 \\
(2)\end{array}$ & $\begin{array}{l}3.50 \\
(2)\end{array}$ & $\begin{array}{l}12.20 \\
(7)\end{array}$ & $\begin{array}{c}15.79 \\
(9)\end{array}$ & $\begin{array}{l}8.33 \\
(2)\end{array}$ & $\begin{array}{l}25 \\
(6)\end{array}$ & - & $\begin{array}{c}50 \\
(12)\end{array}$ & - & $\begin{array}{c}16.67 \\
(4)\end{array}$ \\
\hline $\begin{array}{l}\text { Wing Bow feather } \\
\text { color }\end{array}$ & $\begin{array}{c}68.42 \\
(39)\end{array}$ & $\begin{array}{c}14.03 \\
(8)\end{array}$ & $\begin{array}{c}17.54 \\
(10)\end{array}$ & - & - & $\begin{array}{c}16.67 \\
(4)\end{array}$ & $\begin{array}{c}20.85 \\
(5)\end{array}$ & - & $\begin{array}{l}62.5 \\
(15)\end{array}$ & - & - \\
\hline $\begin{array}{l}\text { Wing Bar feather } \\
\text { color }\end{array}$ & $\begin{array}{c}31.58 \\
(18)\end{array}$ & $\begin{array}{l}5.26 \\
(3)\end{array}$ & $\begin{array}{c}63.16 \\
(36)\end{array}$ & - & - & $\begin{array}{c}8.33 \\
(2)\end{array}$ & $\begin{array}{l}12.50 \\
(3)\end{array}$ & $\begin{array}{c}16.66 \\
(4)\end{array}$ & $\begin{array}{c}50 \\
(12)\end{array}$ & - & $\begin{array}{c}12.5 \\
(3)\end{array}$ \\
\hline $\begin{array}{l}\text { Wing Bay feather } \\
\text { color }\end{array}$ & $\begin{array}{c}80.70 \\
(46)\end{array}$ & $\begin{array}{l}5.26 \\
(3)\end{array}$ & $\begin{array}{c}7.02 \\
(4)\end{array}$ & $\begin{array}{l}5.26 \\
(3)\end{array}$ & $\begin{array}{l}5.26 \\
(3)\end{array}$ & $20.83 \quad(5)$ & $\begin{array}{l}12.50 \\
(3)\end{array}$ & $\begin{array}{c}12.5 \\
(3)\end{array}$ & $\begin{array}{c}54.17 \\
(13)\end{array}$ & - & - \\
\hline Primary feather color & $\begin{array}{c}35.09 \\
(25)\end{array}$ & $\begin{array}{c}14.03 \\
(8)\end{array}$ & $\begin{array}{c}3.50 \\
(2)\end{array}$ & $\begin{array}{c}15.79 \\
(9)\end{array}$ & $\begin{array}{c}22.76 \\
(13)\end{array}$ & $\begin{array}{c}45.83 \\
(11)\end{array}$ & $\begin{array}{l}4.17 \\
(1)\end{array}$ & - & $\begin{array}{l}25 \\
(6)\end{array}$ & - & $\begin{array}{l}25 \\
(6)\end{array}$ \\
\hline
\end{tabular}

*Figures in the parentheses indicate the number of observation.

male but only pale brown color was observed in females $(62.5$ and $54.17 \%$, respectively) for these two parameters. The major wing bar feather color was red $(63.16 \%)$ in male and pale brown $(50 \%)$ in female. The dominant primary feather color was black in both sexes. However, different feather colors with various combinations were also observed at minor frequency in both sexes (Table 2). The findings on plumage colors are in agreement with the reports of Roberts (1997); Holligon (2001); Floyd (2001) and Everett (2010) where they mentioned that Aseel has no fixed colors, the principal colors seen being light red and dark red with grouse-colored and red-wheaten females. Grays, spangles, blacks, whites and piles have also been seen in Aseel chicken. In another investigation, Bhuiyan et al. (2005) reported deep purple plumage color in Aseel chicken which partially agrees with the present findings.

\section{Phenotypic Measurements}

Different phenotypic measurements are presented in Table 3.
The average shank length and circumference were measured as $12.79 \pm 0.13$ and $7.8 \pm 0.08 \mathrm{~cm}$, respectively in adult males whereas it was $10.21 \pm 0.25$ and $5.81 \pm 0.21 \mathrm{~cm}$, respectively in adult females. Ulna/Radius length was $11.04 \pm 0.07$ and $8.96 \pm 0.23 \mathrm{~cm}$, respectively, in males and females. Keel length was $14.39 \pm 0.19 \mathrm{~cm}$ in males while it was $10.79 \pm 0.23 \mathrm{~cm}$ in females. The average adult live weight in male and female birds was measured 3,749.12 \pm 83.44 and 2,062.50 $\pm 105.26 \mathrm{~g}$, respectively. The present findings on mature live weight are similar with the report of Bhuiyan et al. (2005) and Helal (2002) where they found that the adult body weight of Aseel chicken ranged between $1.7 \sim 4.5 \mathrm{~kg}$. According to the British Poultry Standard (Roberts, 1997) the adult live weight was reported $1.8 \sim 2.70 \mathrm{~kg}$ in cock and $1.35 \sim 2.25 \mathrm{~kg}$ in hen, and American Standard of Perfection (1998) reported the average live weight of cock and hen to be $2.49 \mathrm{~kg}$ and $1.81 \mathrm{~kg}$, respectively. All of these observations are relatively low as compared to the present findings. Differences of varieties cho- 
Table 3. Morphological measurements of Aseel chicken

\begin{tabular}{|c|c|c|c|c|c|c|c|c|}
\hline \multirow{2}{*}{ Trait } & \multicolumn{4}{|c|}{ Male } & \multicolumn{4}{|c|}{ Female } \\
\hline & $\mathrm{n}$ & Min & Max & Mean \pm SE & $\mathrm{n}$ & Min & Max & Mean \pm SE \\
\hline Shank length $(\mathrm{cm})$ & 57 & 11.00 & 15.00 & $12.79 \pm 0.13$ & 24 & 9.00 & 14.00 & $10.21 \pm 0.25$ \\
\hline Ulna/Radius length $(\mathrm{cm})$ & 57 & 10.00 & 12.50 & $11.04 \pm 0.07$ & 24 & 7.00 & 11.00 & $8.96 \pm 0.23$ \\
\hline Keel length (cm) & 57 & 12.00 & 18.00 & $14.39 \pm 0.19$ & 24 & 10.0 & 14.00 & $10.79 \pm 0.23$ \\
\hline Shank circumference $(\mathrm{cm})$ & 57 & 6.28 & 8.79 & $7.8 \pm 0.08$ & 24 & 4.71 & 8.16 & $5.81 \pm 0.21$ \\
\hline Adult live weight (g) & 57 & 2,200 & 5,000 & $3,749.12 \pm 83.44$ & 24 & 1,100 & 3,100 & $2,062.50 \pm 105.26$ \\
\hline
\end{tabular}

$\mathrm{n}=$ number of observation, Min $=$ Minimum, Max $=$ Maximum.

sen might be one of the factors for this deviation. Relatively lower shank length and keel length of Aseel chicken were reported by Chatterjee et al. (2007). They found the mean value of shank length and keel length to be $9.52 \pm 5.14$ and $8.40 \pm$ $1.04 \mathrm{~cm}$, respectively at 16 week of age. Age of the bird and combined measurements on both sexes might be the contributing factors for obtaining lower value.

\section{Reproductive Performance of Aseel Hen}

Table 4 depicts that the average age at $1^{\text {st }}$ lay was $28.86 \pm$ 1.40 week in Aseel hen and total number of eggs laid per year ranged between 24 to 48 (average $35.71 \pm 1.68$ ). Number of clutch/hen/year varied from 2 to 4 and number of eggs/ clutch/hen was found 10 12 (average 10.71 \pm 0.26 ). The average egg weight was estimated $40.69 \mathrm{~g}$ and the hatchability of egg was 71.68\%. Agarwal and Sapra (1971) reported average egg weight of Aseel hen was below 40 g. Umesh et al. (2000) reported the average egg production/year, egg weight and hat-

Table 4. Reproductive performance of Aseel hen

\begin{tabular}{lrrrrr}
\hline \hline \multicolumn{1}{c}{ Trait } & n* & $\begin{array}{c}\text { Mini- } \\
\text { mum }\end{array}$ & $\begin{array}{c}\text { Maxi- } \\
\text { mum }\end{array}$ & Mean \pm SE \\
\hline Age at 1st lay (weeks) & 18 & 24 & 40 & $28.86 \pm 1.40$ \\
Number of clutch per year & 18 & 2 & 4 & $3.36 \pm 0.17$ \\
Number of eggs per clutch & 18 & 10 & 12 & $10.71 \pm 0.26$ \\
Total number of eggs per year & 17 & 24 & 48 & $35.71 \pm 1.68$ \\
Egg weight (g) & 15 & 37 & 48 & $40.69 \pm 0.82$ \\
Hatchability of eggs (\%) & 14 & 0 & 100 & $71.68 \pm 9.59$ \\
\hline
\end{tabular}

$* \mathrm{n}=$ number of observation. chability were $33.17,41 \mathrm{~g}$ and 73.97\%, respectively, Moreover, Bhuiyan et al. (2005) reported that age at $1^{\text {st }}$ lay was 240 230 day in Aseel hen and number of eggs production/ hen/year was 33. All of the above findings coincide with of the present study. However, Mohon et al. (2000) reported higher arithmetic mean for egg weight in Aseel chicken which was $47.81 \pm 0.18 \mathrm{~g}$.

\section{Growth Performance of Aseel Chicken}

Growth performance of Aseel chicken up to 17 weeks of age under intensive management system was recorded. The mean live weight of day old chick was found to be $31.14 \mathrm{~g}$. The average live weight at $1,2,3,4,6,8,10,12,16$ and 17 weeks of age were $31.14 \pm 0.55,48.63 \pm 3.99,116.57 \pm 5.72$, $138.40 \pm 5.91, \quad 212.88 \pm 4.82, \quad 361.00 \pm 9.72, \quad 577.50 \pm 42.86$, $743.75 \pm 24.65,1,086 \pm 26.02,1,402 \pm 24.54$ and $1,432 \pm 27.00$ $\mathrm{g}$, respectively. The current observations on growth performance of Aseel chicken are higher than the result of Chatterjee et al. (2007). They reported the average live weight of Aseel chicken at $2,4,8,12$, and 16 weeks of age to be $65.1 \pm 1.04,154 \pm$ $2.39,393 \pm 8.52,796 \pm 13.12$ and $1,218 \pm 19.0$ g, respectively under deep liter management system. This discrepancy might be due to different genotypes and management practices. To compare the growth performance of available indigenous chicken genetic resources of Bangladesh data on non-descript Deshi, Naked Neck and Hilly chicken under intensive management system were included in this study from Faruque et al. (2007) and is presented in Fig. 3. It is showed that the initial growth performance was almost similar up to 4 weeks of age among the four chicken genotypes (Aseel, Hilly, Naked Neck and nondescript Deshi). After that relatively higher growth performance 


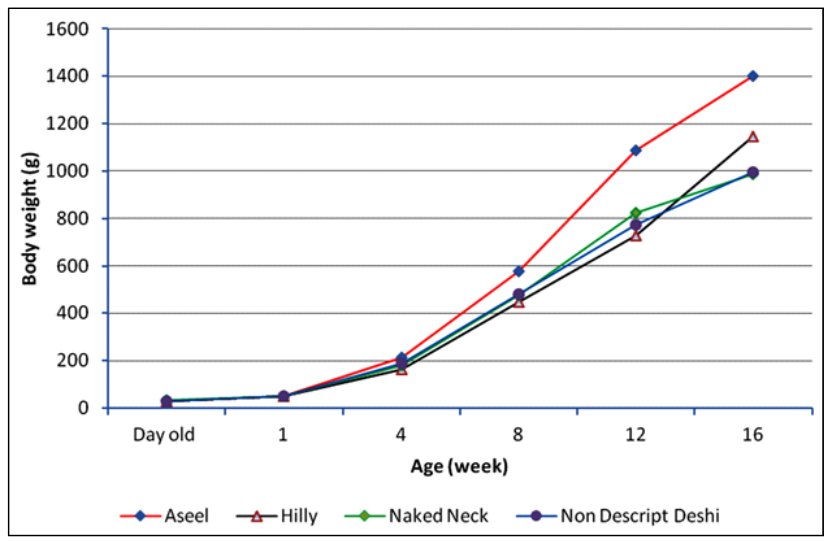

Fig. 3. Comparison of live weight in different indigenous chicken genotypes of Bangladesh (courtesy: Faruque et al., 2007).

was observed in Aseel chicken as compared to other three indigenous genotypes. These findings are supported by the reports of Singh et al. (1999) and Chatterjee et al. (2007). Singh et al. (1999) reported that the juvenile body weight of both sexes of Dahlem Red were higher than those of Naked Neck and Aseel. But at 20 weeks of age Aseel males and females were significantly $(p<0.05)$ heavier than Dahlem Red and Naked Neck. In another investigation, Chatterjee et al. (2007) reported body weight gain of Aseel was highest between 12 16 weeks of age whereas Kadaknath was highest between $8 \sim 12$ weeks of age, which indicated highest gain in body weight of Aseel was still better in higher ages.

\section{CONCLUSION}

Aseel is a world famous game bird which has been maintained over the years mostly by the game bird farmers in Sarail upazila of Brahmanbaria district, and members of cock fighting club in urban and city dwellers of Bangladesh. This study was the first attempt to characterize elaborately the morphological features of Aseel chicken in Bangladesh. But this phenotypic characterization could not ascertain the genetic structure of this breed or variety and is ultimately realized the need for the genetic characterization based on molecular techniques at genome level. However, the present study gives some basic information on Aseel chicken which could be useful for taking any on-ward attempt to prevent from genetic dilution of this valuable genetic resource through conservation and utilization.

\section{LITERATURE CITED}

Agarwal CK, Sapra KL 1971 Growth, mortality and carcass traits of indigenous and exotic purebreds and their crosses. Ind Vet J 49:1008-1012.

Bhuiyan AKFH, Bhuiyan MSA, Deb GK 2005 Indigenous chicken genetic resources in Bangladesh: Current status and future outlook. Anim Genet Resou Infor 36:73-84.

Chatterjee RN, Sharma RP, Reddy MR, Niranjan M, Reddy BLN 2007 Growth, body conformation and immune-responsiveness in two Indian native chicken breeds. Livestock Research for Rural Development, Poultry Genetics and Breeding, Rajendranagar, Hyderabad (Andhra Pradesh), India, 19:151.

Everett C 2010 Asils in the United States, Society for the Preservation of Poultry Antiquities (SPPA) Bulletin. 15:3-4.

Faruque S, Sarker NR, Islam MN, Sarker MSK 2007 Performance of native chicken under intensive system. J Bang Agril Univer 5:283-288.

Floyd J 2001 The Asil, Society for the Preservation of Poultry Antiquities (SPPA) Bulletin. 6:4.

Helal M 2002 Geographical distribution, classification, characterization and conservation of different native chicken varieties of Bangladesh. MS Thesis, Department of Poultry Science, Bangladesh Agricultural University, Mymensingh, Bangladesh.

Holligon S 2001 The Asil, Society for the Preservation of Poultry Antiquities (SPPA) Bulletin. 6:5.

Maeda Y, Okada I, Hasnath MA, Faruque MO, Majid MA, Islam MN 1987 Blood protein polymorphisms of native fowl and red jungle fowl in Bangladesh: Genetic studies on breed differentiation of the native domestic animals in Bangladesh. 2:27-45.

MOFL (Ministry of Fisheries and Livestock) 2004 First Report on the World's Animal Genetic Resources (AnGR) -The Country Report of Bangladesh. p. 9.

Mohan S, Umesh S, Gurung BS 2000 Evaluation of egg weight and its various measurements attributes in indigenous Aseel breed of chicken. Ind J Poult Sci 35:312-314.

Roberts V 1997 British Poultry Standards (5 ${ }^{\text {th }}$ edn.) Blackwell Science Ltd., UK, pp. 45-46.

Singh VK, Mani M, Verma SB, Mandal KG, Singh DP 1999 
Analysis of body weights at different ages in pure and crossbred chicken. Ind J Poult Sci 34:155-160.

The American Poultry Association (APA) 1998 The American Standard of Perfection. pp. 186-187.
Umesh S, Gupta RK, Mohan S, Gurung BS 2000 Reproduction and production performance of Aseel, an indigenous breed of chicken. Ind J Poult Sci 35:202-204.

(submitted: 2011. 10.31, revised: 2011. 12.24, accepted: 2011.12. 28) 